\title{
Effect of oxygen on the degradability of organic matter in subtidal and intertidal sediments of the North Sea area
}

\author{
Birgit Dauwe*, Jack J. Middelburg ${ }^{* *}$, Peter M. J. Herman \\ Netherlands Institute of Ecology, Korringaweg 7, 4401 NT Yerseke, The Netherlands
}

\begin{abstract}
The effect of oxygen on the degradation of sedimentary organic matter has been determined for 6 subtidal stations and 3 intertidal stations in the North Sea area. The stations were selected to cover a range of organic matter lability and sediment texture (and hence concentrations of organic matter). Slurry incubations revealed that at low mineralisation rates, aerobic mineralisation is significantly faster than anaerobic mineralisation, irrespective of the degree of lability of organic matter. A complementary incubation experiment with sediment rich in organic carbon mixed with varying proportions of organically poor sediments confirmed the enhanced aerobic mineralisation at low mineralisation levels. It is proposed that oxygen-enhanced degradation occurs at low mineralisation levels at which bacterial biomass production becomes limiting.
\end{abstract}

KEY WORDS: Organic matter · Degradation $\cdot$ Oxygen $\cdot$ Sediments $\cdot$ North Sea $\cdot$ Intertidal

Resale or republication not permitted without written consent of the publisher

\section{INTRODUCTION}

In most coastal sediments, aerobic decomposition is limited to the upper few millimetres and to the walls of ventilated animal burrows (Aller 1982), whereas anaerobic decomposition is the major mineralisation process in the deeper layers of the sediment column (Jørgensen 1983). The influence of sedimentary redox conditions on mineralisation rates is still a matter of debate. Knowledge of the effect of oxygen on the degradability of organic matter is required to better define the factors governing the preservation of organic matter in marine sediments (Canfield 1994, Hartnett et al. 1998, Hulthe et al. 1998). Decomposition of organic matter is usually modelled as having a firstorder or higher-order (Westrich \& Berner 1984, Middelburg 1989) dependence on organic matter content, independent of oxidant availability and bacterial bio-

\footnotetext{
*Present address: RIKZ, Postbus 8039, 4330 EA Middelburg, The Netherlands

${ }^{* *}$ Corresponding author.

E-mail: middelburg@cemo.nioo.knaw.nl
}

mass (Boudreau 1999). If oxygen affects the degradability of organic matter, this will require revision of diagenetic models. Moreover, benthic animals may rapidly displace organic material from the oxic to the anoxic layers of sediments and vice versa (Aller 1994). Hence, these organisms could thus affect the degradability of organic matter (Aller \& Aller 1998).

Much effort has consequently been devoted to determining whether aerobic mineralisation is faster than anaerobic mineralisation. Even though there is experimental evidence that mineralisation rates of labile sedimentary organic matter are not significantly different under oxic and anoxic conditions (e.g. Westrich \& Berner 1984, Canfield 1989, Lee 1992, Andersen 1996), other studies have shown that some (refractory) compounds of the organic matter degrade more slowly under anoxic than under oxic conditions (Hansen \& Blackburn 1991, Sun et al. 1993a,b, Cowie et al. 1995, Harvey et al. 1995, Hulthe et al. 1998). Other experimental studies have come to the conclusion that anaerobic processes may even be faster than aerobic processes (e.g. Kristensen \& Blackburn 1987, Hulthe et al. 1998). It has been suggested that the lability of organic 
matter determines its relative susceptibility to aerobic versus anaerobic decay (Hulthe et al. 1998), but also source differences (even though they may be corelated to quality) probably play a role (Benner et al. 1984, Kristensen et al. 1995).

Geoscientists have reported field evidence of an effect of oxygen on organic matter degradation on long time scales. Wilson et al. (1985) observed that organic matter in a relict deep-sea turbidite from the Madeira abyssal plain exhibited little degradation over a 140000 yr period when exposed to sulphate, but that $80 \%$ of the carbon was respired within $10000 \mathrm{yr}$ in the presence of oxygen. Canfield (1994) presented evidence that preservation of organic matter was depending on bottom-water oxygen concentrations at low, but not at high, sediment accumulation rates. More recently, Hartnett et al. (1998) gave correlative evidence that the period of time that organic matter is exposed to oxygen determines the efficiency of the mineralisation processes. Sediment accumulation rates and oxygen exposure times comprise many factors known to affect mineralisation on decadal and millennial time scales.

Most experimental results and field studies support the hypothesis that the quality of the organic matter controls whether oxygen affects the mineralisation process. However, sediments with more refractory organic matter showing an oxygen-dependent degradability usually also have low organic matter concentrations, with the result that mineralisation rates are also low. We hypothesise that there is a critical level of mineralisation of organic matter below which aerobic degradation is faster than anaerobic degradation. In marine sediments, the concentration and lability of organic matter often co-vary because they both decrease upon degradation. To uncouple the effect of organic matter lability and mineralisation level from the oxygen dependence of mineralisation, we have made a cross-system study in coastal sediments of the North Sea area. Six subtidal stations and 3 intertidal stations were selected to cover a range of organic matter of various lability and sediment texture (and hence concentrations of organic matter) (Dauwe \& Middelburg 1998, Dauwe et al. 1999). Moreover, sediment that was rich in organic matter from 1 intertidal site was mixed with sediment of low organic matter content to lower the mineralisation level while maintaining the quality of the organic matter constant.

\section{MATERIALS AND METHODS}

Sampling. Sediment samples were taken from 6 subtidal stations in the North Sea in November 1995 (Fig. 1, Table 1: Stns Skagerrak [SK], German Bight [GB], Friesian Front [FF], Broad Fourteens [BF]) and in May 1996 (Brouwershavensche-gat [Stns BG-A, BGB]). Three intertidal stations were sampled in June 1996, 2 located on a tidal flat in the Westerschelde (Molenplaat: [Stns Mol-2 and Mol-3]) and 1 on a musselbank in the Oosterschelde (Stn Zandkreek [ZK]) (Fig. 1, Table 1). At the North Sea stations, most fresh organic matter originates from the deposition of phytoplankton blooms. The sedimentary organic matter reflects a broad sequence of different organic matter degradation states, probably due to ageing during lateral bed-load transport with residual currents and differences in water depth (Dauwe \& Middelburg 1998). In the intertidal areas, fresh organic matter input is dominated by primary production of benthic microalgae at Stns Mol-2 and Mol-3 (Barranguet et al. 1997) and strong biodeposition of organic matter as faeces on

Table 1. Characteristics of sampling stations (labelled as in Fig. 1) and conditions of the incubation experiments. Values in parentheses are for surface 0 to $1 \mathrm{~cm}$ layer of sediment

\begin{tabular}{|c|c|c|c|c|c|c|c|c|c|c|c|c|c|}
\hline \multirow[t]{3}{*}{ Stn } & \multirow[t]{3}{*}{ Latitude } & \multirow[t]{3}{*}{ Longitude } & \multirow{3}{*}{$\begin{array}{l}\text { Depth } \\
\text { (m) }\end{array}$} & \multirow{3}{*}{$\begin{array}{l}\text { Sedim } \\
\text { Median } \\
\text { grain size } \\
(\mu \mathrm{m})\end{array}$} & \multirow{3}{*}{$\begin{array}{l}\text { TOnt } \\
\text { TOC } \\
\text { (wt } \% \text { ) }\end{array}$} & \multirow{3}{*}{$\begin{array}{l}\text { Sampling } \\
\text { period }\end{array}$} & \multirow{2}{*}{\multicolumn{2}{|c|}{$\begin{array}{l}\text { Incubation } \\
\text { period (d) }\end{array}$}} & \multirow{3}{*}{$\begin{array}{c}\text { Inc } \\
T \\
\left({ }^{\circ} \mathrm{C}\right)\end{array}$} & \multirow{2}{*}{\multicolumn{2}{|c|}{$\begin{array}{l}\text { zubation - } \\
\text { Gas }\end{array}$}} & \multirow{2}{*}{\multicolumn{2}{|c|}{$\mathrm{pH}$}} \\
\hline & & & & & & & & & & & & & \\
\hline & & & & & & & Oxic & Anoxic & & Oxic & Anoxic & Oxic & Anoxic \\
\hline \multicolumn{14}{|l|}{ Subtidal } \\
\hline GB & $8^{\circ} 09^{\prime} \mathrm{E}$ & $54^{\circ} 05^{\prime} \mathrm{N}$ & 20 & (16) 31 & 1.12 & Nov 95 & 21 & 22 & 16 & $\mathrm{~N}_{2} / \mathrm{O}_{2}$ & $\mathrm{~N}_{2}$ & $6.9 \pm 0.3$ & $7.1 \pm 0.1$ \\
\hline SK & $10^{\circ} 15^{\prime} \mathrm{E}$ & $58^{\circ} 12^{\prime} \mathrm{N}$ & 270 & (13) 12 & 2.47 & Nov 95 & 19 & 20 & 16 & $\mathrm{~N}_{2} / \mathrm{O}_{2}$ & $\mathrm{~N}_{2}$ & $6.6 \pm 0.3$ & $7.3 \pm 0.1$ \\
\hline FF & $4^{\circ} 30^{\prime} \mathrm{E}$ & $53^{\circ} 42^{\prime} \mathrm{N}$ & 39 & (40) 83 & 0.51 & Nov 95 & 20 & 21 & 16 & $\mathrm{~N}_{2} / \mathrm{O}_{2}$ & $\mathrm{~N}_{2}$ & $7.1 \pm 0.05$ & $7.2 \pm 0.07$ \\
\hline $\mathrm{BF}$ & $3^{\circ} 52^{\prime} \mathrm{E}$ & $53^{\circ} 00^{\prime} \mathrm{N}$ & 28 & (266) 248 & 0.05 & Nov 95 & 22 & 22 & 16 & $\mathrm{~N}_{2} / \mathrm{O}_{2}$ & $\mathrm{~N}_{2}$ & $7.0 \pm 0.15$ & $7.1 \pm 0.04$ \\
\hline BG-A & $3^{\circ} 48^{\prime} \mathrm{E}$ & $51^{\circ} 45^{\prime} \mathrm{N}$ & 5 & (162) 185 & 0.16 & May 96 & 27 & 27 & 16 & $\mathrm{~N}_{2} / \mathrm{O}_{2}$ & $\mathrm{~N}_{2}$ & $6.9 \pm 0.1$ & $7.3 \pm 0.24$ \\
\hline BG-B & $3^{\circ} 46^{\prime} \mathrm{E}$ & $51^{\circ} 46^{\prime} \mathrm{N}$ & 3 & (305) 354 & 0.02 & May 96 & 27 & 27 & 16 & $\mathrm{~N}_{2} / \mathrm{O}_{2}$ & $\mathrm{~N}_{2}$ & $7.0 \pm 0.07$ & $7.3 \pm 0.13$ \\
\hline \multicolumn{14}{|c|}{ Intertidal } \\
\hline Mol-2 & $3^{\circ} 57^{\prime} 2^{\prime} \mathrm{E}$ & $51^{\circ} 26^{\prime} 3^{\prime} \mathrm{N}$ & - & (70) 120 & 0.52 & Jun 96 & 22 & 22 & 16 & $\mathrm{~N}_{2} / \mathrm{O}_{2}$ & $\mathrm{~N}_{2}$ & $6.9 \pm 0.15$ & $7.4 \pm 0.16$ \\
\hline Mol-3 & $3^{\circ} 56^{\prime} 9^{\prime} \mathrm{E}$ & $51^{\circ} 26^{\prime} 25^{\prime} \mathrm{N}$ & - & 180 & 0.18 & Jun 96 & 22 & 22 & 16 & $\mathrm{~N}_{2} / \mathrm{O}_{2}$ & $\mathrm{~N}_{2}$ & $7.0 \pm 0.23$ & $7.3 \pm 0.15$ \\
\hline ZK & $3^{\circ} 54^{\prime} \mathrm{E}$ & $51^{\circ} 33^{\prime} \mathrm{N}$ & - & (238) 190 & 0.25 & Jun 96 & 29 & 29 & 16 & $\mathrm{~N}_{2} / \mathrm{O}_{2}$ & $\mathrm{~N}_{2}$ & $7.3 \pm 0.08$ & $6.9 \pm 0.1$ \\
\hline
\end{tabular}




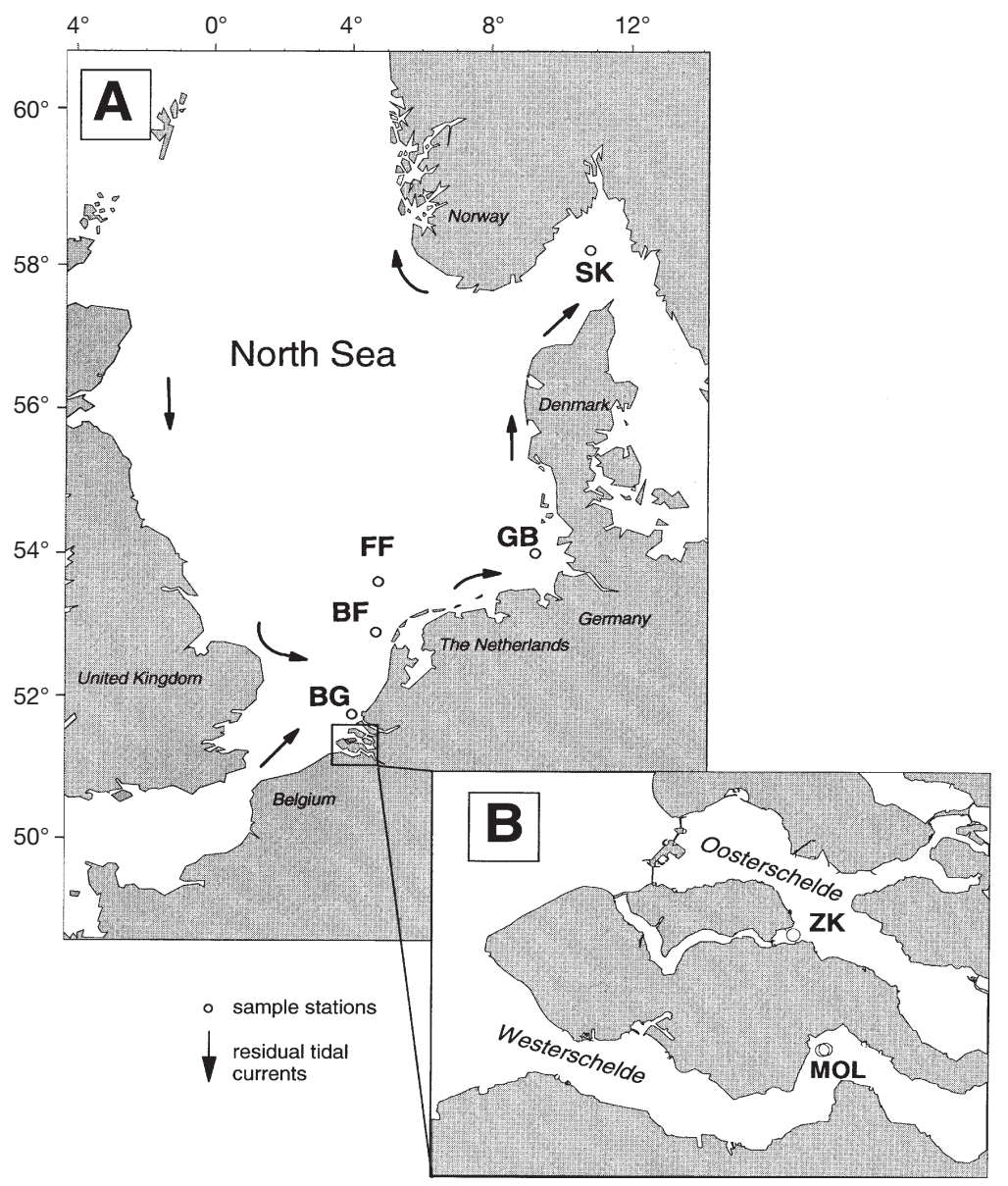

Fig. 1. Locations of sampling stations. (A) North Sea stations: SK = Skagerrak; $\mathrm{GB}=$ German Bight $; \mathrm{FF}=$ Friesian Front $; \mathrm{BF}=$ Broad Fourteens $; \mathrm{BG}=$ Brou wershavensche gat A and B. (B) Intertidal stations: $\mathrm{Mol}=$ Molenplaat 2 and 3; ZK = Zandkreek screw caps provided with rubber septa. This resulted in a slurry:headspace ratio of 30:40 ml. Headspaces were purged 3 times for $10 \mathrm{~min}$ with $\mathrm{N}_{2}$ for the anoxic incubations and with $\mathrm{N}_{2}: \mathrm{O}_{2}(80: 20)$ for the oxic incubations. Between flushings, the slurries were shaken and allowed to equilibrate for $10 \mathrm{~min}$. Bottles containing only gas and bottles containing gas and filtered seawater were used as controls. Final changes in control flasks without sediment were always $<3 \%$ of initial concentrations. Other controls containing sediment and water were poisoned by adding $1 \mathrm{ml}$ of $1 \% \mathrm{HgCl}$. There was no significant $\mathrm{CO}_{2}$ release from poisoned sediments. $\mathrm{CH}_{4}$ release in the anoxic incubations was maximally $2 \%$ of $\mathrm{CO}_{2}$ release, and was therefore ignored. During the whole incubation period, the flasks were continuously rotated, allowing an optimal exchange between the slurry and the headspace gas (van der Nat et al. 1997). All slurries and controls were incubated in the dark at $16^{\circ} \mathrm{C}$ for about 20 to $30 \mathrm{~d}$ (Table 1). This length of incubation was necessary to ensure sufficient accuracy for low-activity samples. A selection of samples covering the entire activity range was incubated 10 -fold under oxic and anoxic conditions to study the kinetics of degradation. $\mathrm{CO}_{2}$ production rates were linear for $>40 \mathrm{~d}$ (Fig. 2), consistent with observations by Hulthe et al. (1998).

the sediments by mussels at Stn ZK (Herman et al. 1999). Samples of the subtidal sediments were obtained with a cylindrical Reineck-type box corer $(31 \mathrm{~cm}$ i.d. [inner diameter]), and subsampled using acrylic tubes (60 cm length, $3.3 \mathrm{~cm}$ i.d.). The intertidal Stns Mol-2, Mol-3 and ZK were sampled by direct coring with acrylic tubes. At each station, 4 subcores were sliced and then pooled per depth stratum and then mixed. All macrofauna and shell fragments were removed prior to incubation. At Stns Mol-2 and Mol-3, replicate sediment oxygen-consumption rates were measured using a shipboard core-incubation technique (Moodley et al. 1998).

Degradability of organic matter. Degradability of organic matter was assessed by measuring the production of $\mathrm{CO}_{2}$ and $\mathrm{CH}_{4}$, the end products of carbon mineralisation, in the headspace above sediment-water slurries. A volume of $\sim 20 \mathrm{ml}$ sediment was transferred into $70 \mathrm{ml}$ glass incubation bottles (Chrompack), and diluted with $10 \mathrm{ml}$ filtered seawater; the bottles were sealed with
Headspace concentrations of $\mathrm{CO}_{2}, \mathrm{O}_{2}$ and $\mathrm{CH}_{4}$ were determined using a Carlo Erba high-resolution MEGA 5340 gas chromatograph, equipped with a flame ioni-

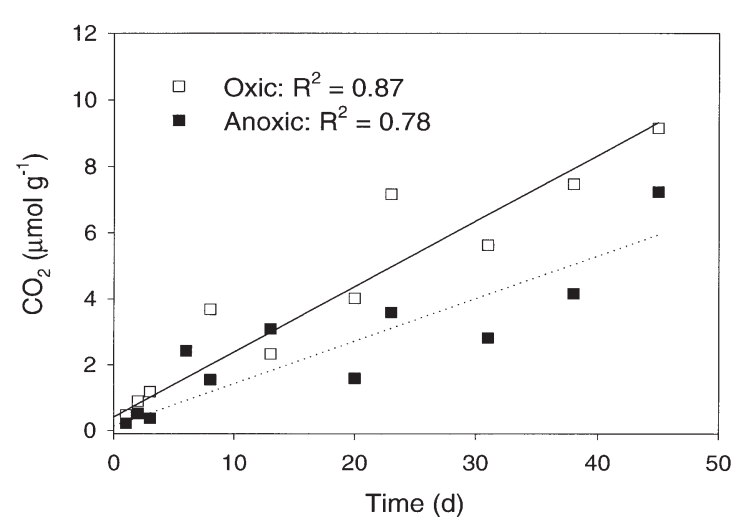

Fig. 2. Example of the evolution of $\mathrm{CO}_{2}$ produced during an oxic and an anoxic incubation. Regression lines and coefficients of determination are shown 

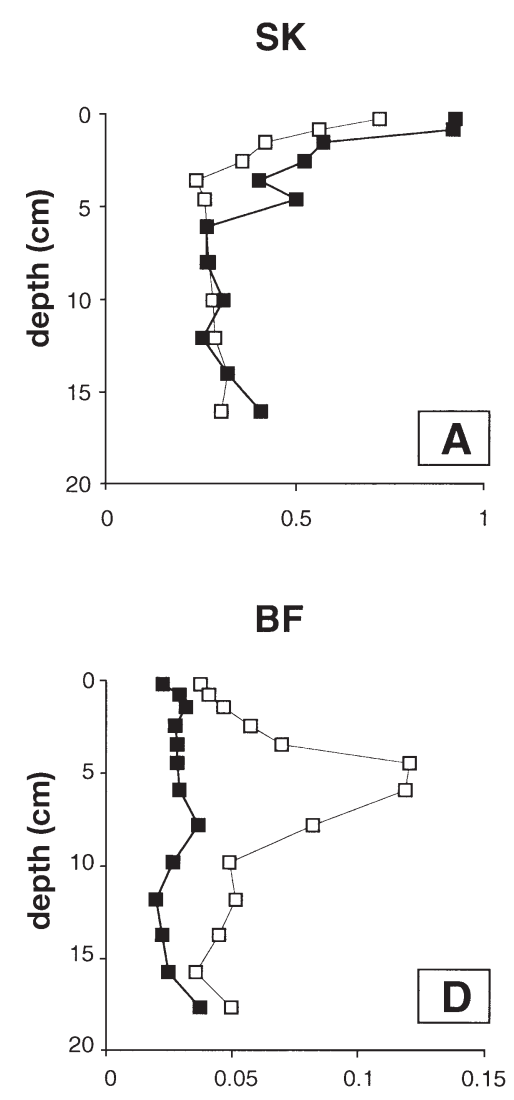

Mol-2

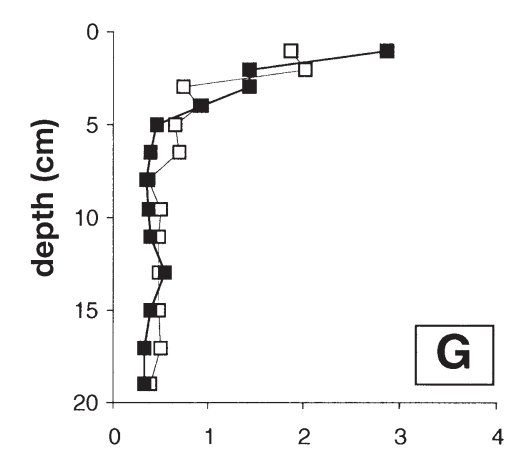

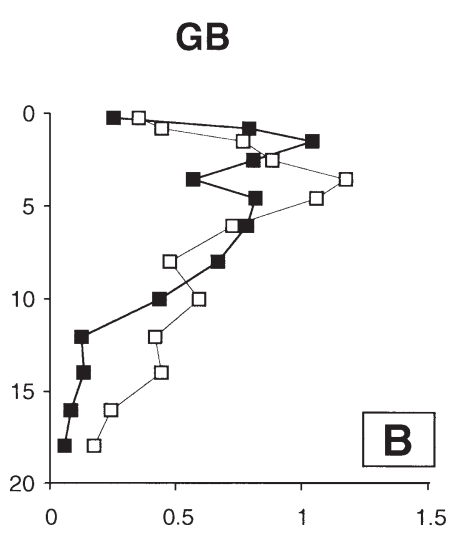

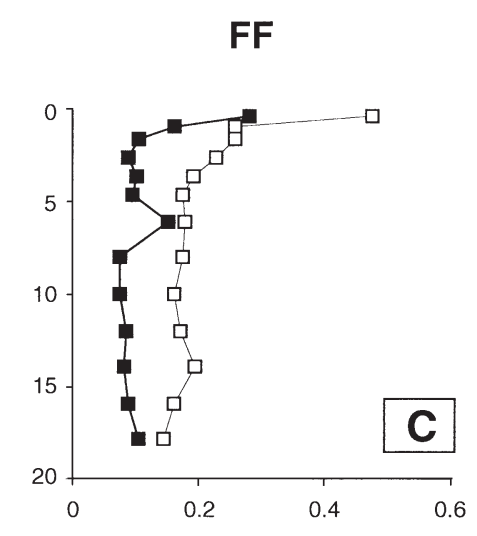

BG-A

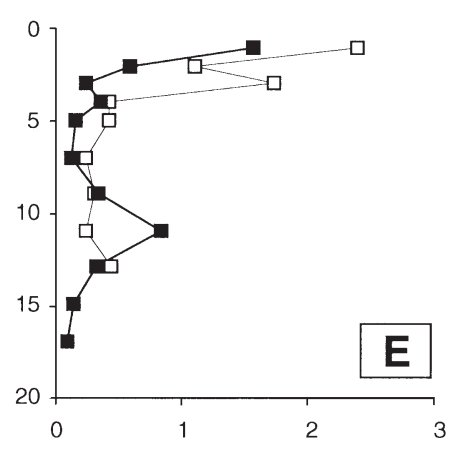

Mol-3

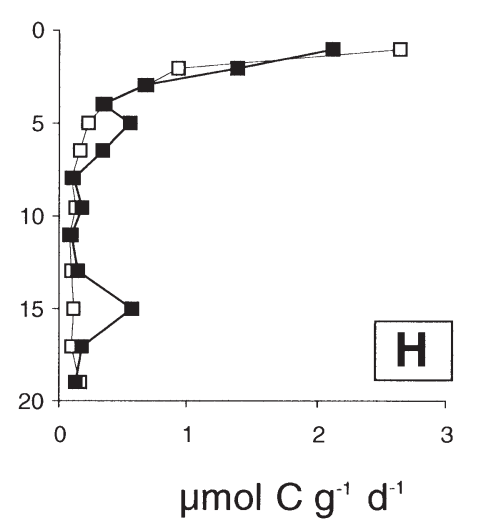

BG-B

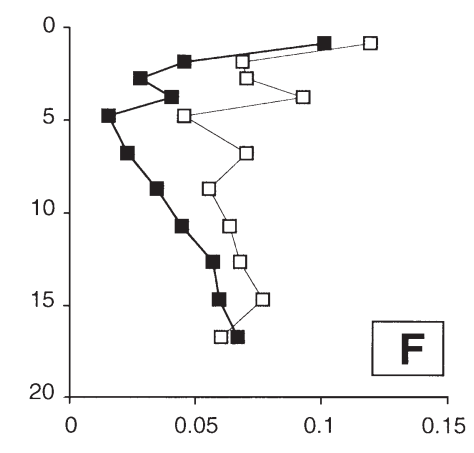

ZK

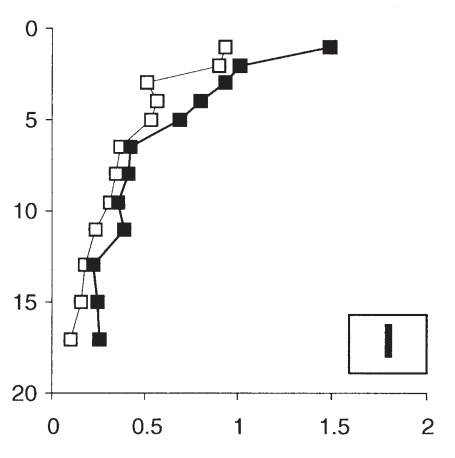

Fig. 3. Vertical profiles of $\mathrm{CO}_{2}$ production per g dry sediment at sampling stations (labelled as in Fig. 1). (ㅁ) Oxic incubations; (घ) anoxic incubations

sation detector, a hot wire detector, a methaniser and a $3 \mathrm{~m}$ Haysep-Q and $2 \mathrm{~m}$ molsieve column. At the end of the incubations, the vials were opened and the $\mathrm{pH}$ was measured. The samples were weighed, freeze-dried, and weighed again in order to determine the dry weight and exact volume of the incubated sediment.

The total amount of gas produced or remaining in the incubation bottles was calculated as the sum of the headspace and dissolved concentrations. Equilibrium concentrations of the gases in the sediment-water slurries are based on measured headspace concentrations and temperature- and salinity-dependent solubility coefficients. For $\mathrm{CO}_{2}$, the pH-dependent speciation was also taken into account (Stumm \& Morgan 1996). All mineralisation rates were expressed as $\mu$ mol $\mathrm{CO}_{2}$ (g dry sediment) $)^{-1} \mathrm{~d}^{-1}$, abbreviated as $\mu$ mol $\mathrm{C} \mathrm{g}^{-1} \mathrm{~d}^{-1}$. Analytical reproducibility of total $\mathrm{CO}_{2}$ measurements is about $5 \%$, taking into account inherent uncertainties 
in $\mathrm{CO}_{2}$ gas measurements in the head space and in slurry pH measurements.

$\mathrm{CO}_{2}$ production generally resulted in some acidification at the end of the experiment during aerobic mineralisation compared to the anoxic incubations (Table 1), probably due to the buffering capacity of many of the anaerobic reaction products (e.g., $\mathrm{HCO}_{3}{ }^{-}$, $\mathrm{H}_{2} \mathrm{~S}$ and $\mathrm{NH}_{4}^{+}$) and sulphide oxidation in the oxic incubations. The oxygen concentration in the oxic slurries was $234 \mu \mathrm{mol}^{-1}$ at the beginning of the incubation and 15 to $80 \mu \mathrm{mol} \mathrm{l}^{-1}$ after $3 \mathrm{wk}$ at the stations with high mineralisation rates (Stns SK and GB); this is well above the $3 \mu \mathrm{mol} \mathrm{l} \mathrm{l}^{-1}$ which comprises the half-saturation constant for $\mathrm{O}_{2}$ limitation in aerobic mineralisation (Gaillard \& Rabouille 1992).

Preparation of sediment mixture. Surface sediment ( 0 to $1 \mathrm{~cm}$ ) was collected at the intertidal Stn Mol-2 on November 23, 1998. The sediment was freeze-dried and diluted to $25,6.25,1.56$ and $0.39 \%$ by adding an organically poor sediment mixture $(0.03 \mathrm{wt} \%)$ of extra pure sand (Merck) and freeze-dried North Atlantic deep-sea sediment (3:1). The sand:silt ratio of the added mixture was similar to that of the intertidal sediment. These sediment mixtures were incubated as in the preceding subsection. Two replicates were incubated for each of the 3 incubation periods $(20,23$, $31 \mathrm{~d})$.

Sediment parameters. Sediment parameters were determined for a subsample of the initial sample. Median grain sizes were determined for freeze-dried samples with a Malvern Particle Sizer 3600 EC. Porosity was calculated from water content (weight loss on drying at $100^{\circ} \mathrm{C}$ ) assuming a dry density of $2.5 \mathrm{~kg} \mathrm{dm}^{-3}$ for sediment. After in situ acidification with $25 \% \mathrm{HCl}$ in precleaned silver cups to remove inorganic carbon (Nieuwenhuize et al. 1994), organic carbon concentrations were determined as total carbon.

\section{RESULTS}

At most stations, carbon dioxide production decreased strongly with increasing depth, except at Stn BF (Fig. 3). Very steep profiles were found at the intertidal Stns Mol-2, Mol-3 and ZK (>90\% decrease with respect to surface mineralisation), whereas the rates at Stns SK, FF, BG-A and BG-B decreased more gradually (60 to $75 \%$ of original surface concentration at $5 \mathrm{~cm}$ depth). At Stn GB, degradable carbon initially increased with increasing depth and then decreased (Fig. 3B). Depth-integrated (0 to $15 \mathrm{~cm}$ ) carbon dioxide production, based on the average of oxic and anoxic incubation, varied from 12 to $140 \mathrm{mmol} \mathrm{m} \mathrm{m}^{-2}$ (Fig. 4A); the sequence was: Mol-2 $>\mathrm{ZK}=\mathrm{GB}=\mathrm{Mol}-3$ $>\mathrm{BG}-\mathrm{A}>\mathrm{SK}=\mathrm{FF}>\mathrm{BG}-\mathrm{B}=\mathrm{BF}$.
Vertical profiles measured under oxic and anoxic conditions had similar shapes at most stations (Fig. 3), except at Stn BF where the aerobic profile showed an extended subsurface peak, whereas the anaerobic profile remained constant with depth. The consistent differences between carbon dioxide production under oxic and anoxic conditions over the entire sediment depth (Fig. 3) were reflected by the ratio of aerobic versus anaerobic mineralisation rates based on depthintegrated $\mathrm{CO}_{2}$ production (Fig. 4B). The aerobic mineralisation rate was significantly higher than the anaerobic rate at the coarse-grained Stn FF ( $\mathrm{n}=13, \mathrm{p}<$ 0.001), BF ( $\mathrm{n}=13, \mathrm{p}<0.001)$, and BG-B ( $\mathrm{n}=11, \mathrm{p}<$ 0.001 ) sediments, with ratios of aerobic rate versus anaerobic rate of between 1.7 and 2.7. At the other stations, aerobic and anaerobic mineralisation rates were similar (Stns GB, BG-A, Mol-2, Mol-3) or anaerobic rates were even slightly higher $(\operatorname{Stn} \mathrm{SK}, \mathrm{n}=12, \mathrm{p}=$ 0.03; Stn ZK, $\mathrm{n}=12, \mathrm{p}=0.003$ ).

A log-log plot of aerobic versus anaerobic mineralisation rate is given for all sediments that had an oxygen concentration of more than $80 \mu \mathrm{mol} \mathrm{O} \mathrm{O}^{-1}$ at the end of the oxic incubations (Fig. 5A). The slope of the geometric mean regression line $(1.41 \pm 0.074)$ is significantly different from 1 (Student's $t$-test, $\mathrm{n}=57, \mathrm{p}<$ 0.001 ), indicating that mineralisation rates of sedimentary organic matter are different under anoxic compared to oxic conditions. Although the differences at intermediate to high mineralisation rates were mar-

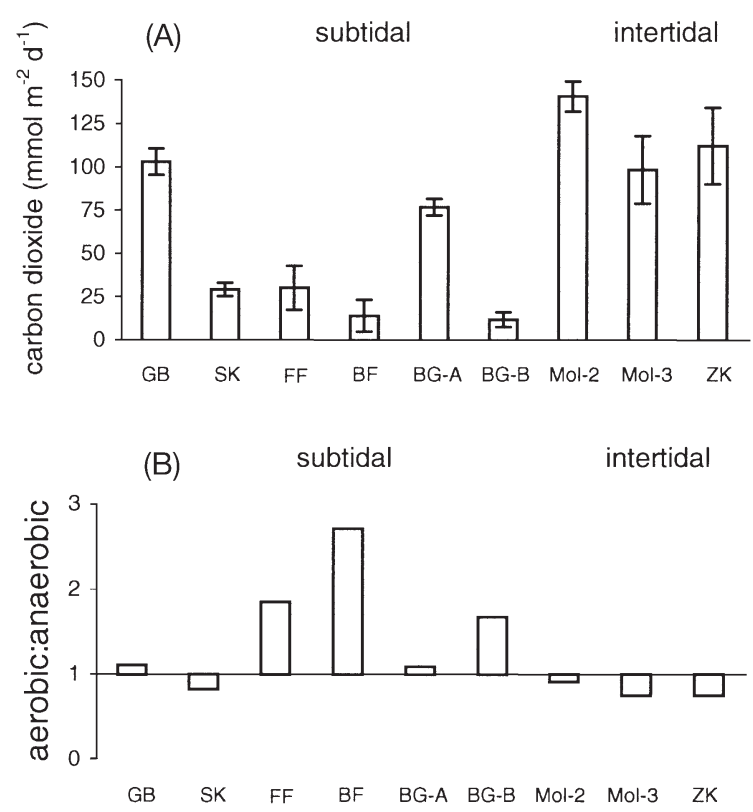

Fig. 4. (A) Depth-integrated (0 to $15 \mathrm{~cm}$ ) carbon dioxide production $(\bar{x} \pm \mathrm{SD}$ aerobic and anaerobic mineralisation); (B) ratio of depth-integrated aerobic versus anaerobic mineralisation. Sampling stations (abscissas) labelled as in Fig. 1 

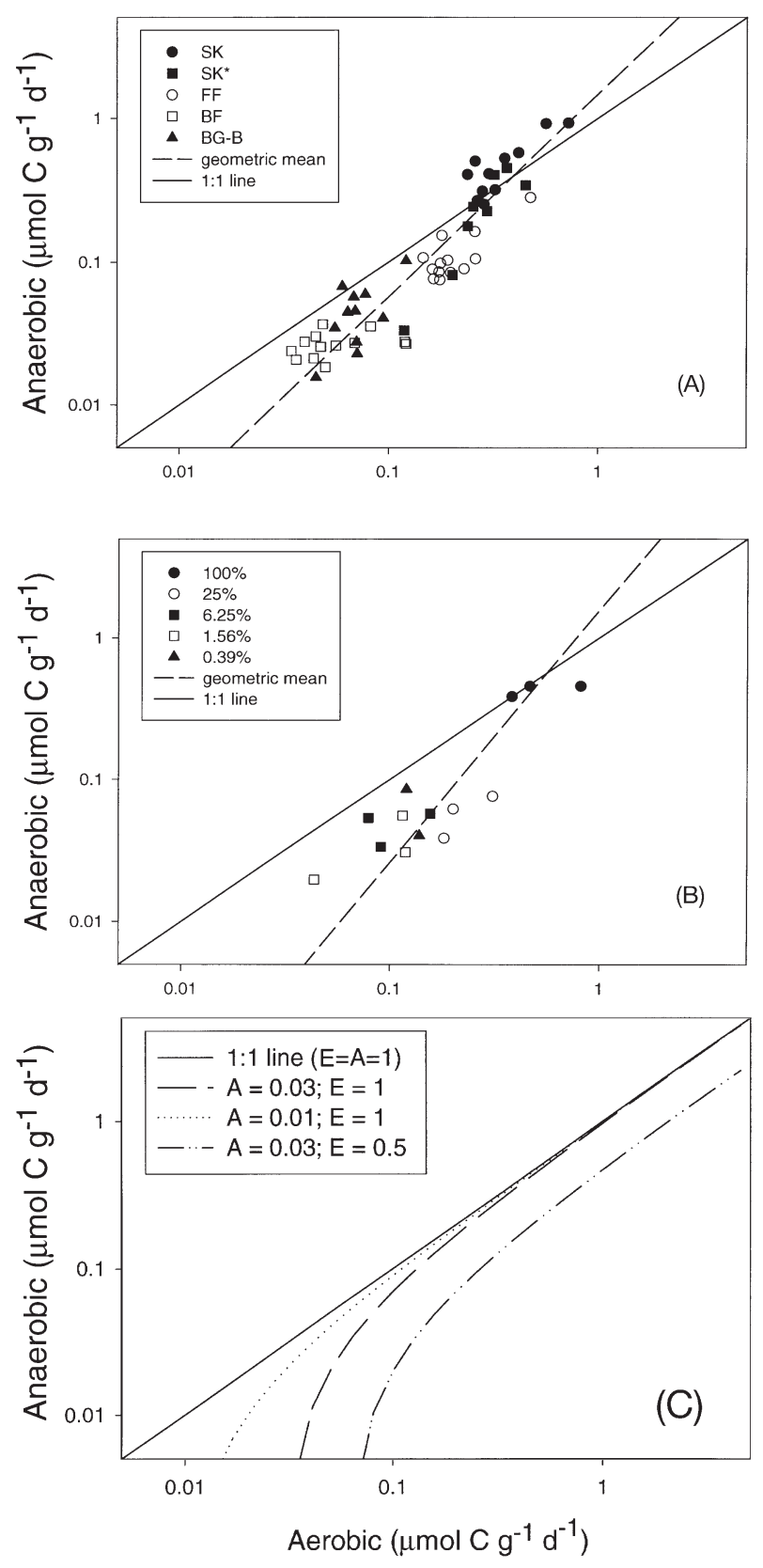

Fig. 5. Log-log plots of aerobic versus anaerobic mineralisation rates. (A) Sedimentary organic matter from Stns SK, FF, $\mathrm{BF}$ and BG-B, at all depth intervals (SK* : data from Hulthe et al. [1998]: see 'Discussion'), showing 1:1 and geometric mean regression lines; (B) dilution experiment with percentage of original sediment, showing 1:1 and geometric mean regression lines; $(\mathrm{C})$ model results for $\mathrm{A}=0.03, \mathrm{E}=1 ; \mathrm{A}=0.01, \mathrm{E}=1$; and $\mathrm{A}=0.03, \mathrm{E}=0.5(\mathrm{~A}=$ constant $; \mathrm{E}=$ efficiency factor $)$

ginal, at low mineralisation rates $\left(<0.1 \mu \mathrm{mol} \mathrm{C} \mathrm{g}^{-1} \mathrm{~d}^{-1}\right)$, typical for the sandy Stns BF and BG-B (Fig. 5A), aerobic mineralisation was up to $50 \%$ higher than rates measured under anoxic conditions.

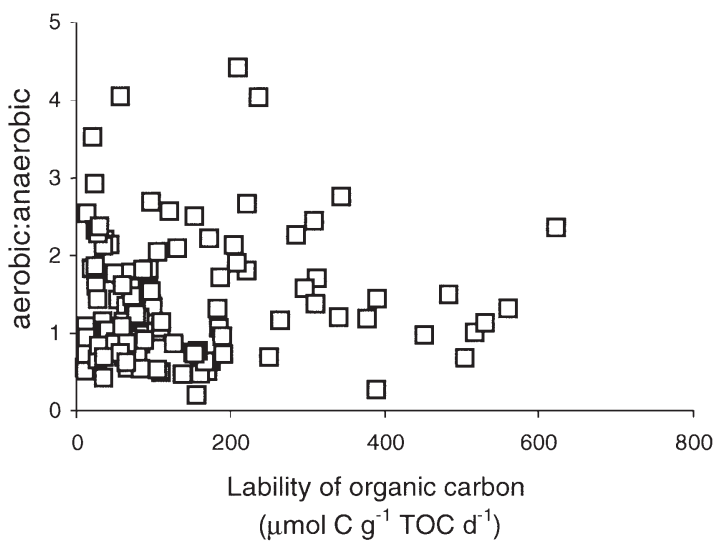

Fig. 6. Ratio between measured aerobic and anaerobic mineralisation rates as a function of the lability of organic carbon (defined as the mineralisation rate divided by the organic carbon content of the sedimentary organic matter). TOC: total organic carbon

To investigate whether the observed differences between aerobic and anaerobic mineralisation rates correlated with the lability of the organic matter, the ratio of aerobic versus anaerobic rate was plotted against the lability of the organic matter expressed as the amount of carbon mineralised per gram total organic carbon (TOC) per day (Fig. 6). There was no clear trend in the ratio over the large range of lability measured for sedimentary organic matter ( 10 to $\left.>600 \mu \mathrm{mol} \mathrm{C} \mathrm{g}^{-1} \mathrm{TOC} \mathrm{d}^{-1}\right)$.

During incubation of the sediment dilution series, dissolved oxygen concentrations were always above $140 \mu \mathrm{M}$. Fig. 5B shows the log-log plot of aerobic versus anaerobic degradation. Again, the slope of the geometric mean regression $(1.77 \pm 0.19)$ is significantly different from 1 ( $t$-test, $\mathrm{n}=13, \mathrm{p}<0.006$ ) and aerobic mineralisation is faster than anaerobic mineralisation at low mineralisation rates.

\section{DISCUSSION}

\section{Methodological aspects}

Before discussing the results and literature, it is instructive to distinguish between experiments in which the entire sediment column is exposed directly to oxygen and experiments using sediment cores and manipulating the oxygen content of the overlying water. In the latter, only the top few millimetres of the sediment are affected by the oxygen regime in the overlying water column, because oxygen typically becomes depleted within the upper 0 to $15 \mathrm{~mm}$ and most mineralisation will occur anaerobically (apart from animal tubes etc. that may enable oxygen to protrude deeper into the sediment). The complete oxygenation/de-oxygenation of all depth strata in slurry incubations is comparable to 
the 'thin layer technique' (e.g. Sun et al. 1993b), and enables us to assess the effect of oxygen on degradation independently from oxygen diffusion.

Mineralisation rates based on slurry incubations may deviate from in situ rates because slicing and homogenisation of the sediment horizons may disturb microgradients of nutrients and enlarge the solid-liquid ratio so that micro-organisms have easier access to organic matter (Aller \& Aller 1998). However, studies of the effects of slurry incubations on bacterial production rates are not equivocal (Burdige 1989). The presence of mineral surfaces may stimulate rates of incorporation of organic substrates, even by 1 order of magnitude in slurries (Meyer-Reil 1986), or inhibit incorporation rates compared to undisturbed sediments (Dobbs et al. 1989), depending on the substrate, mineral and organism involved.

Depth-integrated carbon dioxide production ranged from 12 to $140 \mathrm{mmol} \mathrm{m}^{-2} \mathrm{~d}^{-1}$ (Fig. 4A) and covered the whole range of mineralisation rates in estuarine and coastal sediments $\left(7\right.$ to $90 \mathrm{mmol} \mathrm{m} \mathrm{m}^{-2} \mathrm{~d}^{-1}$ : Heip et al. 1995). A direct site-by-site comparison of available literature data on oxygen uptake by North Sea sediments (Cramer 1990, van Raaphorst et al. 1992, Boon \& Duineveld 1998) with our integrated rates of carbon dioxide production is complicated by temperature differences, interannual and seasonal variability and the absence of macrofauna in our incubations (for details see Dauwe 1999). However, during the sampling period, sediment oxygen-uptake rates were measured at Stns Mol-2 and Mol-3, being $175 \pm 37$ and $95 \pm 4 \mathrm{mmol} \mathrm{O}_{2} \mathrm{~m}^{-2} \mathrm{~d}^{-1}$, respectively. There is good agreement with carbon dioxide production rates based on slurry incubations (141 \pm 9 and $99 \pm 19$ mmol CO $\mathrm{Cm}^{-2} \mathrm{~d}^{-1}$ at Stns Mol-2 and Mol3 , respectively). Whatever bias there may be in our slurry estimates relative to in situ rates, the comparative aspect in terms of aerobic versus anaerobic mineralisation is considered representative of natural sediment.

\section{Aerobic versus anaerobic mineralisation}

The results of this study indicate that differences between aerobic and anaerobic mineralisation rates are mainly related to the absolute rate (Figs. $4 \& 5$ ) and not to the lability of the sedimentary organic matter (Fig. 6). Generally, the decay rate of sedimentary organic matter was rather similar in oxic and anoxic incubations (Figs. 3 \& 5). In coarse-grained sediments characterised by very low mineralisation rates (less than about $0.1 \mu \mathrm{mol} \mathrm{C} \mathrm{g}^{-1} \mathrm{~d}^{-1}$ ) such as those found at Stns BF and BG-B, mineralisation rates under oxic conditions were consistently and significantly higher than those under anoxic conditions at all investigated depths (Fig. 3). The depth-consistent divergence in the coarse-grained sediments is reflected by the significant deviation ( $t$-test, $\mathrm{n}=57, \mathrm{p}<0.001$ ) of the slope of the geometric mean regression line through the aerobic versus the anaerobic mineralisation rate (slope = $1.41 \pm 0.074$ ) from the 1:1 line (Fig. 5A). To ascertain that oxygen did not become limiting at the end of the experiment (the critical level is about $3 \mu \mathrm{mol} \mathrm{O} \mathrm{O}^{-1}$ : Gaillard \& Rabouille 1992), we included only samples with a final $\mathrm{O}_{2}$ concentration well above this level (containing $>80 \mu \mathrm{mol} \mathrm{O} \mathrm{O}_{2} \mathrm{l}^{-1}$ ) in the geometric mean regression. Inclusion of data points from stations for which we had no information on the final oxygen concentration (Stns BG-A, Mol-2, Mol-3, ZK) or from stations at which the final oxygen concentration decreased to $\sim 15 \mu \mathrm{mol} \mathrm{l}^{-1}$ (Stn GB) would not change the significant deviation of the geometric mean regression (slope = $1.24 \pm 0.054)$ from the $1: 1$ line $(t$-test, $\mathrm{n}=120, \mathrm{p}<0.001)$. The ratio of aerobic versus anaerobic mineralisation did not vary systematically over the broad range of organic matter lability investigated in this study (about 10 to $>600 \mu \mathrm{mol} \mathrm{C} \mathrm{g}^{-1}$ TOC d $^{-1}$ : Fig. 6).

The sediment dilution series incubations (Fig. 5B) provided additional support for a critical level of mineralisation rather than organic matter lability controling the effect of oxygen on mineralisation rates. The mineralisation rate per unit weight varied, while the composition of the organic matter undergoing degradation remained constant. The slope of the geometric mean regression of the sediment dilution experiment $(1.77 \pm 0.19)$ differed significantly from 1 , and the point of intersection with the $1: 1$ line $\left(0.57 \mu \mathrm{mol} \mathrm{C} \mathrm{g}^{-1} \mathrm{~d}^{-1}\right.$ : Fig. 5B) was comparable to that obtained in the crosssystem study (0.39 $\mu \mathrm{mol} \mathrm{C} \mathrm{g}^{-1} \mathrm{~d}^{-1}$ : Fig. $\left.5 \mathrm{~A}\right)$.

Our results seem to contrast with studies suggesting that the lability of organic matter determines its susceptibility to aerobic versus anaerobic decay. Usually, redox conditions are considered to have little influence on the degradation rate of labile organic matter, such as algae (Otsuki \& Hanya 1972a,b), homogenised sedimentary organic matter (Kristensen \& Blackburn 1987), plankton material added to sediment cores (Westrich \& Berner 1984, Henrichs \& Reeburgh 1987 , Lee 1992) or labile molecular compounds such as neutral sugars and amino acids (Hedges et al. 1988). In contrast, oxic conditions have been reported to stimulate degradation of more refractory organic material (Kristensen et al. 1995, Sun et al. 1997, Hulthe et al. 1998). Particularly aromatic structures and highly polymeric compounds such as lignin have been found to be poorly degradable under anoxic conditions (Benner et al. 1984). These specific differences in the degradability of terrestrial versus marine organic matter did not affect the results of our study, since the main source of organic matter was marine phytoplankton for the North Sea stations (Dauwe \& Middelburg 1998) and 
estuarine phytoplankton and microphytobenthos for the intertidal Molenplaat stations (Herman et al. 2000, Middelburg et al. 2000).

The relatively low anaerobic mineralisation rates in sediments with low amounts of degradable sedimentary carbon may indicate a critical activity limit below which anaerobic bacterial communities operate less efficiently than aerobic communities. We hypothesise that (1) organic matter mineralisation at low rates depends on the bacterial biomass, and (2) that the oxygen effect at low rates can be attributed to a difference in growth or maintenance efficiency between aerobic and anaerobic bacteria.

In order to better understand the link between mineralisation level, bacterial biomass and the effect of oxygen on mineralisation, we have developed a simple, generic model based on our hypothesis. Mineralisation is a function of the quantity and quality of organic matter $(f(C))$ and has a Monod-type dependence on the biomass of heterotrophic bacteria $(B)$ :

$$
M=f(C) \frac{B}{B+K_{B}}
$$

where $M$ is the mineralisation rate $\left(\mu \mathrm{mol} \mathrm{C} \mathrm{g}^{-1} \mathrm{~d}^{-1}\right)$, $f(C)$ is a function describing the dependence of mineralisation rate on the quality and quantity of organic matter substrate, $B$ is the biomass of metabolically active bacteria ( $\mu \mathrm{mol} \mathrm{C} \mathrm{g}^{-1}$ ), and $K_{B}$ is the Monod halfsaturation constant for the influence of bacterial biomass on mineralisation ( $\mu \mathrm{mol} \mathrm{C} \mathrm{g}^{-1}$ ). The mineralisation rate has a first-order dependence on bacterial biomass at very low biomass, but a zero-order dependence at higher biomass values. This independence of mineralisation from bacterial biomass at high biomass values is consistent with observations and theory (Boudreau 1992). The function $f(C)$ does not have to be specified for our purpose, but it probably can be described by a first-order dependency on labile carbon (Westrich \& Berner 1984, Middelburg 1989, Boudreau 1992). Bacterial biomass evolves according to:

$$
\frac{\mathrm{d} B}{\mathrm{~d} t}=\gamma \cdot M-1 \cdot B
$$

where $\gamma$ is metabolic efficiency (dimensionless), and $l$ is the biomass-specific loss rate (due to mortality and maintenance respiration; $\mathrm{d}^{-1}$ ). When bacteria are assumed to be at steady state with the organic substrate available:

one obtains:

$$
\frac{\mathrm{d} B}{\mathrm{~d} t}=0
$$

$$
M=f(C)-\frac{1}{\gamma} K_{B}
$$

Aerobic (Subscript 1) and anaerobic (Subscript 2) mineralisation are then given by:

$$
M_{1}=f(C)_{1}-\frac{l_{1}}{\gamma_{1}} K_{B 1} \text { and } M_{2}=f(C)_{2}-\frac{l_{2}}{\gamma_{2}} K_{B 2}
$$

respectively.

The model is generic, and study of its behaviour does not require accurate knowledge of parameter values. If the functional dependence of mineralisation of organic matter does not depend on oxygen: i.e. $f(C)_{1}=f(C)_{2}$, then $M_{2}=M_{1}-A$, where

$$
A=\frac{l_{2}}{\gamma_{2}} K_{B 2}-\frac{l_{1}}{\gamma_{1}} K_{B 1} \text { and } A<f(C)
$$

for physically real solutions.

Anaerobic bacteria may have a lower metabolic efficiency $(\gamma)$ and/or a higher biomass-specific loss rate, $l$ (more biomass must be respired for the same energy gain) than aerobic bacteria, and $A$ is therefore positive and finite. Model results for $A>0$ clearly illustrate that aerobic mineralisation becomes faster than anaerobic mineralisation at low activity levels (Fig. 5C). Adoption of other values for $A$ will change the actual values of mineralisation but not the general appearance of the model (Fig. 5C): i.e. an oxygen effect at low mineralisation rates, in agreement with our observations.

If the functional dependence of organic matter does depend on oxygen so that $f(C)_{2}=E \cdot f(C)_{1}$, then $M_{2}=$ $E \cdot M_{1}-A^{\prime}$, where $A^{\prime}$ is a constant and $E$ is an efficiency factor (dimensionless). Such dependence on oxygen would result in data parallel to the 1:1 line, but shifted towards lower values over the entire range (Fig. 5C). Accordingly, it appears that the observed oxygen effect is consistent with a model based on limitation of mineralisation by bacterial biomass at low mineralisation levels, and a difference in growth and maintenance efficiency of aerobic and anaerobic bacteria.

If our hypothesis of a 'critical limit' of mineralisable carbon needed to sustain anaerobic mineralisation is valid, then the same stimulatory effect of oxygen on degradation rate should be displayed not only by sediments characterised by low amounts of labile organic matter, as at Stns BF and BG-A, but also by sediments characterised by large amounts of refractory organic matter. The data on mineralisation rates at different stations in the Skagerrak area (Hulthe et al. 1998) can be used as an independent check. Hulthe et al. incubated surface and subsurface sediments for up to $60 \mathrm{~d}$ under controlled oxic and anoxic conditions. Fig. 5A shows that the mineralisation rates of their refractory organic matter falls in the same range of the labile organic matter in our coarse-grained sediments at Stns BF and BG-B. Below about $0.1 \mu \mathrm{mol} \mathrm{C} \mathrm{g}^{-1} \mathrm{~d}^{-1}$, both sediment types showed consistently higher degrada- 
tion rates under oxic conditions, regardless of their contrasting lability: 1 to $23 \mu \mathrm{mol} \mathrm{C} \mathrm{g}^{-1} \mathrm{TOC} \mathrm{d}^{-1}$ at the Skagerrak stations of Hulthe et al. and about 100 to $300 \mu \mathrm{mol} \mathrm{C} \mathrm{g}{ }^{-1} \mathrm{TOC} \mathrm{d}^{-1}$ at Stns BF and BG-B.

A lower critical mineralisation level control of the oxygen dependence of mineralisation is also consistent with field observations. Enhanced oxidation arising from downward progressing oxidation fronts has been reported for deep-sea turbiditic (Wilson et al. 1985, Cowie et al. 1995) and sapropelic (Pruysers et al. 1993) sediments with low mineralisation rates. Canfield (1994) compiled evidence for enhanced preservation of organic matter in slowly accumulating sediments. Slowly accumulating (deep-sea) sediments are generally also characterised by low mineralisation levels (Canfield 1994, Middelburg et al. 1997). The divergence of oxic and anoxic preservation occurs at an accumulation rate in the order of $0.03 \mathrm{~cm} \mathrm{yr}^{-1}$ (Canfield 1994), which represents a mineralisation rate in the order of $3 \mathrm{mmol} \mathrm{m}^{-2} \mathrm{~d}^{-1}$ or $0.02 \mu \mathrm{mol} \mathrm{C} \mathrm{g}^{-1} \mathrm{~d}^{-1}$ (using data compiled by Middelburg et al. 1997). This is consistent with a critical level of mineralisation as inferred from our cross-system and sediment dilution series incubations.

In conclusion, a cross-system analysis and sediment dilution approach revealed that aerobic mineralisation of marine sedimentary material is faster at low mineralisation levels, irrespective of the quality of organic matter. The effect of oxygen on the degradation of organic matter becomes apparent below a critical mineralisation level at which bacterial biomass may limit mineralisation. Consistently, unequivocal field evidence for an oxygen effect has only been reported for slowly accumulating deep-sea sediments with low mineralisation activities. Finally, our study has clearly documented that the effect of oxygen on mineralisation depends not only on the source, degradation state and chemical composition of particulate organic matter (Benner et al. 1984, Canfield 1994, Kristensen et al. 1995, Hulthe et al. 1998), but also on the mineralisation rate.

Acknowledgements. Pieter van Rijswijk, Adri Sandee and Elfriede Burgers are gratefully acknowledged for their assistance with sediment sampling and with incubation experiments. Joop Nieuwenhuize, Bart Schaub and Yvonne Maas are thanked for their assistance with the GC measurements. The crews of RV 'Pelagia' and RV 'Luctor' are thanked for their support and pleasant stay during the cruise. Carlo Heip and the anonymous reviewers are gratefully acknowledged for critically reading the manuscript. The research was financially supported by the Netherlands Organisation for the Advancement of Science (NWO), project VvA, under grant 770-18-235 and the European Union ELOISE programme (projects ECOFLAT (ENV4-CT96-026) and PHASE (MAS3CT96-0053)). This is ELOISE contribution 165 and publication no. 2680 of the Netherlands Institute of Ecology.

\section{LITERATURE CITED}

Aller RC (1982) The effects of macrobenthos on chemical properties of marine sediment and overlying water. In: McCall PL, Tevesz MJS (eds) Animal-sediment relations. Plenum Press, New York, p 53-102

Aller RC (1994) Bioturbation and remineralisation of sedimentary organic matter: effects of redox oscillation. Chem Geol 114:331-345

Aller RC, Aller JY (1998) The effect of biogenic irrigation intensity and solute exchange on diagenetic reaction rates in marine sediments. J Mar Res 56:905-936

Andersen F (1996) Fate of organic carbon added as diatom cells to oxic and anoxic marine sediment microcosms. Mar Ecol Prog Ser 134:225-233

Barranguet C, Herman PMJ, Sinke JJ (1997) Microphytobenthos biomass and community composition studied by pigment biomarkers: importance and fate in the carbon cycle of a tidal flat. J Sea Res 38:59-70

Benner R, Maccubbin AE, Hodson RE (1984) Anaerobic biodegradation of the lignin and polysaccharide components of lignocellulose and synthetic lignin by sediment microflora. Appl Environ Microbiol 47:998-1004

Boon AR, Duineveld GCA (1998) Chlorophyll a as a marker for bioturbation and carbon flux in southern and central North Sea sediments. Mar Ecol Prog Ser 162:33-43

Boudreau BP (1992) A kinetic model for microbic organic matter decomposition in marine sediments. FEMS Microbiol Ecol 102:1-14

Boudreau BP (1999) A theoretical investigation of the organic carbon-microbial biomass relation in muddy sediments. Aquat Microb Ecol 17:181-189

Burdige DJ (1989) The effects of sediment slurrying on microbial processes, and the role of amino acids as substrates on sulfate reduction in anoxic marine sediments. Biogeochemistry $8: 1-23$

Canfield DE (1989) Sulfate reduction and oxic respiration in marine sediments: implications for organic carbon preservation in euxinic environments. Deep-Sea Res 36: $121-138$

Canfield DE (1994) Factors influencing organic carbon preservation in marine sediments. Chem Geol 114: 315-329

Cowie GL, Hedges JI, Prahl FG, de Lange GJ (1995) Elemental and major biochemical changes across an oxidation front in a relict turbidite: an oxygen effect. Geochim Cosmochim Acta 59:33-46

Cramer A (1990) Seasonal variation in benthic metabolic activity in a frontal system in the North Sea. In: Barnes M, Gibson RN (eds) Trophic relationships in the marine environment. Proc 24th Eur Mar Biol Symp. University Press of Aberdeen, Aberdeen, p 54-76

Dauwe B (1999) Organic matter quality in North Sea sediments. Thesis, University of Groningen

Dauwe B, Middelburg JJ (1998) Amino acids and hexosamines as indicators of organic matter degradation state in North Sea sediments. Limnol Oceanogr 43:782-798

Dauwe B, Middelburg JJ, van Rijswijk P, Sinke J, Herman PMJ, Heip CHR (1999) Variations of enzymatically hydrolyzable amino acids in North Sea sediments and their possible implication for the nutritional value. J Mar Res 57:109-134

Dobbs FC, Guckert JB, Carman KR (1989) Comparison of three techniques for administering radiolabeled substrates to sediments for trophic studies: incorporation by microbes. Microb Ecol 17:237-250

Gaillard JF, Rabouille C (1992) Using monod kinetics in geo- 
chemical models of organic carbon mineralisation in deepsea surficial sediments. In: Rowe GT, Pariente V (eds) Deep-Sea food chains and the global carbon cycle. Kluwer Academic, Dordrecht, p 309-324

Hansen LS, Blackburn TH (1991) Aerobic and anaerobic mineralisation of organic material in marine sediment microcosms. Mar Ecol Prog Ser 75:283-291

Hartnett HE, Keil RG, Hedges JI, Devol AH (1998) Influence of oxygen exposure time on organic carbon preservation in continental margin sediments. Nature 391: $572-574$

Harvey HR, Tuttle JH, Bell JT (1995) Kinetics of phytoplankton decay during simulated sedimentation: change in biochemical composition and microbial activity under oxic and anoxic conditions. Geochim Cosmochim Acta 59: $3367-3377$

Hedges JI, Clark WA, Cowie GL (1988) Fluxes and reactivities of organic matter in a coastal marine bay. Limnol Oceanogr 33:1137-1152

Heip CHR, Goosen NK, Herman PMJ, Kromkamp J, Middelburg JJ, Soetaert K (1995) Production and consumption of biological particles in temperate estuaries. Oceanogr Mar Biol Annu Rev 33:1-149

Henrichs SM, Reeburgh WS (1987) Anaerobic mineralisation of marine organic matter: rates and the role of anaerobic processes in the ocean carbon economy. Geomicrobiol J 5:191-237

Herman PMJ, Middelburg JJ, van de Koppel J, Heip CHR (1999) Ecology of estuarine macrobenthos. Adv Ecol Res 29:195-240

Herman PMJ, Middelburg JJ, Widdows J, Lucas CH, Heip CHR (2000) Stable isotopes as trophic tracers: combining field sampling and manipulative labelling of food resources for macrobenthos. Mar Ecol Prog Ser 204:79-92

Hulthe G, Hulth S, Hall POJ (1998) Effect of oxygen on degradation rate of refractory and labile organic matter in continental margin sediments. Geochim Cosmochim Acta 62: $1319-1328$

Jørgensen BB (1983) Processes at the sediment-water interface. In: Bolin B, Coock RB (eds) The major biochemical cycles and their interactions. J Wiley \& Sons, New York, p 477-515

Kristensen E, Blackburn TH (1987) The fate of organic carbon and nitrogen in experimental marine sediment systems: influence of bioturbation and anoxia. J Mar Res 45: 231-257

Kristensen E, Ahmed SI, Devol AH (1995) Aerobic and anaerobic decomposition of organic matter in marine sediment: which is fastest? Limnol Oceanogr 40:1430-1437

Lee C (1992) Controls of organic carbon preservation: the use of stratified water bodies to compare intrinsic rates of decomposition in oxic and anoxic systems. Geochim Cosmochim Acta 56:3323-3335

Meyer-Reil LA (1986) Measurement of hydrolytic activity and incorporation of dissolved organic substrates by microorganisms in marine sediments. Mar Ecol Prog Ser 31: $143-149$

Editorial responsibility: Otto Kinne (Editor), Oldendorf/Luhe, Germany
Middelburg JJ (1989) A simple rate model for organic matter decomposition in marine sediments. Geochim Cosmochim Acta 53:1577-1581

Middelburg JJ, Soetaert K, Herman PMJ (1997) Empirical relationships for use in global diagenetic models. DeepSea Res 44:327-344

Middelburg JJ, Barranguet C, Boschker HTS, Herman PMJ, Moens T, Heip CHR (2000) The fate of intertidal microphytobenthos carbon: an in situ ${ }^{13} \mathrm{C}$-labeling study. Limnol Oceanogr 45:1224-1234

Moodley L, Heip CHR, Middelburg JJ (1998) Benthic activity in sediments of the northwestern Adriatic Sea: sediment oxygen consumption, macro-and meiofauna dynamics. J Sea Res 40:263-280

Nieuwenhuize J, Maas YEM, Middelburg JJ (1994) Rapid analysis of organic carbon and nitrogen in particulate materials. Mar Chem 45:217-224

Otsuki A, Hanya T (1972a) Production of dissolved organic matter from dead green algae cells. 1. Aerobic microbial decomposition. Limnol Oceanogr 17:248-257

Otsuki A, Hanya T (1972b) Production of dissolved organic matter from dead green algae cells. 2. Anaerobic microbial decomposition. Limnol Oceanogr 17:258-264

Pruysers PA, de Lange GJ, Middelburg JJ, Hydes D (1993) The diagenetic formation of metal-rich layers in sapropelcontaining sediments in the Eastern Mediterrenean. Geochim Cosmochim Acta 57:527-536

Stumm W, Morgan JJ (1996) Aquatic chemistry. Chemical equilibria and rates in natural waters. Wiley-Interscience, London

Sun MY, Lee C, Aller RC (1993a) Anoxic and oxic degradation of ${ }^{14} \mathrm{C}$-labeled chloropigments and a ${ }^{14} \mathrm{C}$-labeled diatom in Long Island Sound sediments. Limnol Oceanogr 38: 1438-1451

Sun MY, Lee C, Aller RC (1993b) Laboratory studies of oxic and anoxic degradation of chlorophyll $a$ in Long Island Sound sediments. Geochim Cosmochim Acta 57:147-157

Sun MY, Wakeham SG, Lee C (1997) Rates and mechanisms of fatty acid degradation in oxic and anoxic coastal marine sediments of Long Island Sound, New York, USA. Geochim Cosmochim Acta 61:341-355

van der Nat FJWA, de Brouwer JFC, Middelburg JJ, Laanbroek HJ (1997) Spatial distribution and inhibition by ammonium of methane oxidation in intertidal freshwater marshes. Appl Environ Microbiol 63:4734-4740

van Raaphorst WR, Kloosterhuis HT, Berghuis EM, Gieles AJM, Malschaert JFP, van Noort GJ (1992) Nitrogen cycling in two types of sediments of the southern North Sea (Frisian Front, Broad Fourteens): field data and mesocosm results. Neth J Sea Res 28:293-316

Westrich JT, Berner RA (1984) The role of sedimentary organic matter in bacterial sulfate reduction: the $\mathrm{G}$ model tested. Limnol Oceanogr 29:236-249

Wilson TRS, Thomson J, Colley S, Hydes DJ, Higgs NC (1985) Early organic diagenesis: the significance of progressive subsurface oxidation fronts in pelagic sediments. Geochim Cosmochim Acta 49:811-822

Submitted: December 6, 1999; Accepted: September 6, 2000 Proofs received from author(s): April 4, 2001 